\title{
JAN LEBENSTEIN I GALERIE LAMBERT W 1959 ROKU - OKOLICZNOŚCI PIERWSZEJ WYSTAWY
}

\author{
Marta BANASZAK (Uniwersytet Mikołaja Kopernika, Toruń) \\ Mirosław A. SUPRUNIUK (Uniwersytet Mikołaja Kopernika, Toruń)
}

Późnym popołudniem, 15 grudnia 1959 roku odbył się w Galerie Lambert na wyspie Św. Ludwika, w centrum Paryża, wernisaż pierwszej indywidualnej wystawy Jana Lebensteina we Francji ${ }^{1}$. W archiwum galerii zachowało się jedno zdjęcie z tego wydarzenia: to dzięki niemu wiemy, że na otwarciu ekspozycji, obok właścicieli i malarza, oraz zapewne Konstantego A. Jeleńskiego i Józefa Czapskiego, których nie ma na zdjęciu, byli przebywający wówczas w Paryżu: Zbigniew Herbert i rzeźbiarka Alina Ślesińska². Galeria Lambert, w niewielkim lokalu sąsiadującej z Księgarnią Libella kamienicy, o wymiarach: $5 \times 6,30 \times 4 \mathrm{~m}$, dopiero zaczynała swoją działalność. Założona przez właścicieli Libelli - Kazimierza i Zofię Romanowiczów — kilka miesięcy wcześniej, została już jednak dostrzeżona w środowisku paryskich krytyków sztuki dwiema dobrze ocenionymi wystawami: Tadeusza Dominika i Japończyka Josaku Maedy ${ }^{3}$. Wystawa u Romanowiczów była, jak wspomniano wyżej, pierwszą paryską ekspozycją Lebensteina, choć w dniu wernisażu, malarz nie był już postacią zupełnie nieznaną we Francji. Przyczynił się do tego zaskakujący tryumf na pierwszym Biennale des Jeunes de Paris, jesienią roku 1959, na którym Lebenstein zdobył Grand Prix. Suk-

${ }^{1}$ M. A. Supruniuk, Studium bestii. Jan Lebenstein i Galerie Lambert (w 40-lecie pierwszej wystawy), [w:] Jan Lebenstein i krytyka. Eseje, recenzje, wspomnienia, wybór i oprac. A. Wat, D. Wróblewska, wstępem opatrzyła J. Sosnowska, Warszawa 2004, s. 205.

${ }^{2}$ Libella Galerie Lambert. Szkice i wspomnienia, red. i oprac. M. A. Supruniuk, Torun 1998, fot. 15 .

${ }^{3}$ Więcej o Galerie Lambert: M. A. Supruniuk, Galeria ,Wyspy Skarbów”, [w:] Libella Galerie Lambert, s. 85-105. O Herbercie z 1959 roku, zob.: J. Lebenstein, Światlo i przestrzeń, Jan Lebenstein. Rozmowy o sztuce własnej, o tradycji $i$ wspótczesności, wybór i oprac. A. Wat, D. Wróblewska, wstępem opatrzył K. Pomian, Warszawa 2004, s. 204-206. 
ces ten dawał malarzowi prawo wyboru miejsca swojego debiutu, jednak wystawa w Galerie Lambert zaplanowana była i przygotowana wcześniej. Pół roku wcześniej, a to zobowiązywało obie strony umowy do dotrzymania terminów. Wydrukowany w litografii, niewielkich rozmiarów plakat w zielonym kolorze, zawisł na drzwiach galerii kilka dni przed wernisażem. Rozesłane zaproszenia uzupełniała reprodukcja gwaszu. Wystawa była sukcesem. Niemal wszystkie prace zostały sprzedane.

Przedrukowana niżej korespondencja pomiędzy Janem Lebensteinem, Konstantym A. Jeleńskim oraz Kazimierzem Romanowiczem przedstawia okoliczności przygotowania grudniowej wystawy malarza w Galerie Lambert. Aby właściwie ocenić wystawę Lebensteina, zauważyć należy, że przełom lat 50. i 60. był krótkim okresem międzynarodowego „odkrywania” sztuki polskiej nie tylko w Paryżu, którego najważniejszym akcentem stał się udział grupy malarzy i rzeźbiarzy w pierwszym Biennale des Jeunes de Paris w 1959 roku. Zaproszeni zostali: Teresa Pągowska, Alina Szapocznikow, Magdalena Więckówna, Halina Chrostowska, Stefan Gierowski, Jan Tarasin, Tadeusz Dominik, Bronisław Kierzkowski, Rajmund Ziemski, Jan Lebenstein i Józef Gielniak ${ }^{4}$. Zaplanowane w Galerie Lambert indywidualne ekspozycje polskich plastyków miały być, jak się wydaje uzupełnieniem Biennale, zwłaszcza, że galeria Romanowiczów brała udział w projekcie Biennale, tj., była jedną z kilkunastu paryskich galerii, w których pokazywano konkursowe prace i wystawy towarzyszące. Sukcesy międzynarodowe nie oznaczały ułatwień w wymianie kulturalnej Polski ze światem. Po krótkim okresie odwilży w kulturze, kultura została w Polsce ponownie poddana ścisłej kontroli cenzury politycznej. Ograniczono również dostęp do informacji o sukcesach artystów ${ }^{5}$. Dotyczyło to także plastyków. W efekcie, nie wszyscy zapraszani na wystawy światowe otrzymywali paszporty; nie inaczej było z zaproszeniami Galerie Lambert ${ }^{6}$. Wszelako, zarówno w Paryżu jak w Londynie, gdzie chwilę wcześniej powstały dwie polskie galerie sztuki: Drian Gallery i Galeria Grabowskiego ${ }^{7}$, świadomość, że wolność wypowiadania się w sztuce oznacza konieczność konfrontowania własnych dokonań z doświadczeniami sztuki światowej głównie poprzez wystawy za granicą, była oczywista. Galerie Lambert, podobnie jak galerie londyńskie, miała spełnić niemożliwą do przecenienia rolę tratwy ratunkowej dla nowej sztuki polskiej, dla młodych malarzy i rzeźbiarzy. Na ile skuteczną — nie sposób powiedzieć. Nikt nie prowadził tego rodzaju badań.

Inspirującą rolę w tworzeniu zarysu profilu Galerie Lambert miał jak się wydaje Józef Czapski, choć roli tej możemy się jedynie domyślać. To Czapski napisze pierwszy tekst o Galerie, w paryskiej „Kulturze”, wyjaśniając jej założenia i cel powstania:

[Galerie Lambert] nie jest pomyślana jako galeria o wystawach wyłącznie malarzy pol-

skich. Założyciele mają ambicje wystawiania ty $1 \mathrm{k}$ o malarzy z prawdziwego zdarze-

\footnotetext{
${ }^{4}$ M. A. Supruniuk, Studium bestii, s. 205.

${ }^{5}$ Wyjątkiem jest sukces Lebensteina. W 1960 roku program telewizyjny Pegaz pokazał rozmowę Andrzeja Wata z malarzem; zob.: Jan Lebenstein, [w:] Jan Lebenstein. Rozmowy o sztuce własnej, s. 96.

${ }^{6}$ Dotyczyło to np. Ludmiły Murawskiej, której wystawa była planowana w 1959 roku; informacja od malarki.

${ }^{7}$ Pierwszy zwrócił na to uwagę Józef Czapski; zob.: tenże, Galeria Lambert, Kultura 1959 nr 6 (140), s. 142; B. Czaykowski, Galeria Grabowskiego, Kultura 1959 nr 4 (138), s. 122-127. Wyjaśnienia wymaga wpływ powstania Galerii Grabowskiego na decyzję Romanowiczów; zob.: M. A. Supruniuk, Galeria ,,Wyspy Skarbów”, s. 97.
} 
nia, a wśród nich także malarzy polskich, i tych z emigracji, i tych, którzy przybywają tutaj z Polski ${ }^{8}$.

Szybko jednak, zajęty własną sztuką i jej promowaniem, Czapski „odsunie się w cień” i wspierać będzie działalność galerii z oddali, recenzując wystawy; najważniejszą rolę w Galerie Lambert, także ze względów finansowych, odgrywać będzie Konstanty A. Jeleński, przez przyjaciół nazywany Kotem. Mówił o tym Kazimierz Romanowicz, nie pozostawiając wątpliwości co do wagi współpracy z krytykiem i historykiem sztuki, którego stosunki we francuskim świecie artystycznym były nie do przecenienia? Wkład Jeleńskiego w oblicze Galerie Lambert był wielowątkowy. Krytyk podjął się przede wszystkim trudu i obowiązku promocji galerii, tworząc jej wyrazisty i nowy nawet $\mathrm{w}$ warunkach paryskich, profil.

O wyborze Galerie Lambert — pisał w podsumowaniu półtorarocznej działalności nie decyduje styl malarstwa, ale raczej wiek malarza, siła indywidualnego wyrazu. Polska, Jugosławia, Węgry, Japonia, Australia, Boliwia, Indie. W przyszłym sezonie Nigeria, Martynika, Hiszpania, Tunezja. Przeciętny wiek malarzy — bliżej trzydziestki niż czterdziestki. Na małą skalę, bardziej może od innych paryskich galerii, Galerie Lambert świadczy o kurczeniu się świata, a zarazem o sile promieniowania sztuki żywej ${ }^{10}$.

Ten sposób myślenia o polskiej galerii w Paryżu, jako miejscu promowania nowej młodej sztuki światowej, bez cenzury narodowej, wynikał z zaangażowania K. A. Jeleńskiego w działalność Kongresu Wolności Kultury ${ }^{11}$. Zbiegło się w czasie kilka wydarzeń. W 1959 roku, gdy powstała Galerie Lambert, Jeleński z ramienia Kongresu, wspierał organizację pierwszego Biennale młodych artystów w Paryżu, promując młodą sztukę w „Preuves”. Włączenie Galerie Lambert w wielki, międzynarodowy projekt, jakim było Biennale, miało najpewniej na uwadze potencjalne możliwości wprowadzenia jej w obieg krytyki artystycznej. Z tego też względu, w latach późniejszych, Jeleński starał się będzie pozyskiwać dla galerii młodych artystów z całego świata, którzy odnosili sukcesy na konkursach organizowanych przez stowarzyszenia i instytucje afiliowane przy Kongresie Wolności Kultury lub korzystali z kongresowych stypendiów. I należy podkreślić raz jeszcze: nie dotyczyło to wyłącznie twórców z Europy Środkowo-Wschodniej, ale przede wszystkim malarzy i rzeźbiarzy z Azji, Afryki, Ameryki Łacińskiej, a nawet Australii i wszystkich krajów Europy Zachodniej. Podobna działalność promocyjna prowadzona była w tym czasie i w latach późniejszych, w różnych agendach Kongresu, niejednokrotnie z udziałem K. A. Jeleńskiego, również w odniesieniu do muzyków, pisarzy ludzi nauki i polityki ${ }^{12}$.

Nie ulega wątpliwości, że możliwość zaistnienia w paryskim (co wówczas wciąż jeszcze oznaczało - światowym) środowisku sztuki Jan Lebenstein zawdzięczał wszystkim trzem osobom: Jeleńskiemu, Romanowiczowi i Czapskiemu. Udziału Czap-

\footnotetext{
${ }^{8}$ J. Czapski, Galerie Lambert, s. 142-143.

${ }^{9}$ [K. Romanowicz], Totues les femmes sont Polonaises. Rozmowa M. Smorąg, Ex Libris 1994 nr 44, s. 5 (Dod. do: Życie Warszawy 1994 nr 15). Rozmowa Piotra Kłoczowskiego z Janem Lebensteinem o Kocie Jeleńskim, [w:] Jan Lebenstein. Rozmowy o sztuce własnej, s. 187-197.

${ }^{10}$ K. A. J[eleński], Polskie wystawy w Paryżu, Kultura 1960 nr 9 (155), s. 122-124.

${ }^{11} \mathrm{Na}$ temat roli K. A. Jeleńskiego w Kongresie Wolności Kultury więcej: P. Grémion, Konspiracja wolności. Kongres Wolności Kultury w Paryżu (1950-1975), Warszawa 2004, s. 248 i in.; M. A. Supruniuk, Przyjaciele wolności. Kongres Wolności Kultury i Polacy, Warszawa 2008, s. 16 i in.

${ }^{12} \mathrm{Tu}$, choćby działalność: Société des Editions Liberté de la Culture, czy L'Institut national de l'audiovisuel (Ina).
} 
skiego nie krył także Jeleński w listach do właściciela galerii, zaznaczając by kopie korespondencji w sprawie wystawy Lebensteina kierować do Maisons-Laffitte ${ }^{13}$. Dotyczy to zarówno zaproszenia do Galerie Lambert na jesienną wystawę, ale też zaproszenia na Biennale des Jeunes de Paris. Nazwisko Lebensteina znalazło się wśród trzech polskich nazwisk u początków tworzenia programu wystaw nowopowstałej galerii, obok Tadeusza Dominika i Ludmiły Murawskiej. Znalazło się również wśród nazwisk zgłoszonych do Związku Polskich Artystów Plastyków, z prośbą by Związek wytypował pozostałe na wspólną wystawę w Paryżu. Skąd Jeleński znał te trzy nazwiska? Wydaje się, że decydujący wpływ na taki dobór pierwszych artystów miał Józef Czapski, a pośrednio Ludwik Hering, malarz i prozaik, współtwórca Teatru na Tarczyńskiej i Teatru Osobnego Trzech Osób w Warszawie ${ }^{14}$. L. Hering i J. Czapski korespondowali, a nawet rozmawiali ze sobą przez telefon, co wówczas wymagało odwagi ${ }^{15}$. Nie sposób wykluczyć, że pierwsza podróż Lebensteina do Paryża w 1957 roku i spotkanie z Czapskim, a w konsekwencji także z Jeleńskim, odbyła się z inspiracji Heringa ${ }^{16}$. Malarz powie później, że pierwsze spotkanie ze stolicą Francji wypadło źle: „Paryż wypiął się na mnie, więc ja się też wypiąłem na Paryż" ${ }^{17}$. Po raz pierwszy Jeleński wymienił nazwisko Lebensteina w recenzji wystawy malarstwa abstrakcyjnego z Polski (Strzemiński, Kobro), która miała miejsce w 1957 roku w Paryżu. Napisał wówczas, polemizując z opinią Jeana Cassou:

Nie wydaje się jednak, przynajmniej z daleka, aby Lebenstein, Kantor, Urbanowicz, Włodarski, Kujawski, Erna Rosenstein — żeby wymienić kilku malarzy polskich, których znam z oryginałów czy z reprodukcji - wiele zawdzięczali pionierom abstrakcji geometrycznej $^{18}$.

Można jednak przyjąć prostsze wyjaśnienie: w roku 1959 Lebenstein uczestniczył w kilku wystawach zbiorowych, o których można było przeczytać w Paryżu: Biennale w São Paulo w Brazylii, Documenta II w Kassel oraz zbiorowej wystawie polskich artystów w Genewie: Pologne 50 ans de peinture ${ }^{19}$.

Propozycja pokazania obrazów Lebensteina w Paryżu wyszła ze strony Jeleńskiego najpewniej na początku kwietnia 1959 roku. Pisze o tym malarz w pierwszym liście do Romanowicza. Pod koniec miesiąca, w ślad za prywatnym listem Kota, poszło oficjalne zaproszenie ze strony dyrektora i właściciela Galerie Lambert - Kazimierza Romanowicza. Przez kilka miesięcy prowadzona była korespondencja pomiędzy galerią

${ }^{13}$ W Maisons-Laffitte pod Paryżem miał siedzibę Instytut Literacki, tam też, w domu „Kultury”, mieszkał od 1947 roku aż do śmierci w 1993 Józef Czapski.

${ }^{14}$ Murawska. Malarstwo i Teatr Osobny Trzech Osób (Biatoszewski, Hering, Murawska), oprac. M. A. Supruniuk, Toruń 1999, s. [21].

${ }^{15}$ L. Murawska-Peju, Postowie, [w:] L. Hering, Ślady, Warszawa 2011, s. 137. Odwaga Heringa mogła być powodem odmowy paszportu dla Ludmiły Murawskiej, którą się opiekował. $\mathrm{Z}$ zaproponowanych w 1959 roku wystaw nie wszystkie udało się zrealizować. Ludmiła Murawska nie dostała paszportu a jej wystawa doszła do skutku dopiero trzy lata później.

${ }^{16}$ [J. Lebenstein], Moje obrazy sq metaforami emocjonalnymi, rozmowa Z. Jurkiewicza, [w:] Jan Lebenstein. Rozmowy o sztuce własnej, s. 24. J. Lebenstein powie Wiesławie Wierzchowskiej, że to Miron Białoszewski namówił go do spotkania z Miłoszem w Paryżu; J. Lebenstein, Malowanie jest jak pisanie dzienników, rozmowa W. Wierzchowskiej, [w:] Jan Lebenstein. Rozmowy o sztuce wtasnej, s. 50.

${ }^{17}$ J. Lebenstein, Malowanie jest jak pisanie dzienników, s. 46.

${ }^{18}$ K. A. Jeleński, Tryb zaprzeszty czasu przyszłego, Kultura 1958 nr 1-2 (123-124), s. 167.

${ }^{19}$ J. Gola, Jan Lebenstein - Kalendarium, [w:] Jan Lebenstein. Rozmowy o sztuce własnej, s. $218-219$. 
a malarzem, oraz galerią i K. A. Jeleńskim, która uściślała datę wernisażu i warunki wystawy, dostosowując je do udziału Lebensteina w paryskim Biennale. O tym opowiada zamieszczona niżej korespondencja.

Należy uzupełnić korespondencję o informacje, których w listach nie ma, a których echa znajdujemy w innych miejscach. Alarmujące listy Romanowicza w sprawie wiadomości o transporcie obrazów i przyjeździe Lebensteina do Paryża oraz brak odpowiedzi ze strony malarza są najpewniej śladem kłopotów z otrzymaniem paszportu. Potwierdza to zdanie w liście Jeleńskiego do Jerzego Giedroycia z [1961] roku ${ }^{20}$. Planując wystawę i już od lata 1959 roku także udział w Biennale de Paris, Lebenstein przygotował prócz obrazów olejnych również gwasze, które zamierzał wystawić później, może na wiosnę 1960 roku, licząc na pomoc i znajomości J. Czapskiego. Nieoczekiwany sukces na paryskim Biennale postawił zarówno Lebensteina jak i Galerie Lambert w trudnej sytuacji. Nagrodą za pierwsze miejsce w Biennale była możliwość indywidualnej wystawy w bogatej i gwarantującej sukces finansowy Galerie Lacloche, na Placu Vendôme. Za zgodą Romanowicza poszły na nią płótna przywiezione z Polski na ekspozycję planowaną w Galerie Lambert.

Nie broniliśmy - napisze Z. Romanowiczowa - nasza galeria stawiała wtedy pierwsze swoje kroki na paryskim gruncie. Lacloche mógł Lebensteinowi zapewnić nie sławę, bo jej właśnie dostąpił, nie dobre recenzje, bo to i my już mogliśmy mu dać, ale wprowadzenie w inny świat. Ważniejsze to nam się wydawało, niż start materialny galerii z okazji wyróżnienia artysty ${ }^{21}$.

A malarz dodawał:

[...] widząc, że dla moich dalszych losów w Paryżu ta wystawa na placu Vendôme była bardzo ważna, zgodził się oddać obrazy Galerie Lacloche, gdzie był większy lokal i lepsze warunki materialne. To był bardzo ładny gest ${ }^{22}$.

Jednak umowa z Romanowiczami zobowiązywała Lebensteina. Wystawa w Galerie Lambert mogła dojść do skutku, tylko dzięki gwaszom przywiezionym przez malarza z nadzieją na kolejną wystawę paryską. Niewielka ekspozycja trwała od połowy grudnia 1959 roku do połowy stycznia roku następnego i odniosła wielki sukces tak artystyczny, jak finansowy. Ukazało się wiele recenzji i obszerne artykuły poświęcone Galerie Lambert i malarzowi. W jednym z nich, zatytułowanym Galeria Romanowiczów, Kazimierz Wierzyński (nieco myląc dwie równoczesne wystawy) napisał:

Galeria stała się modna; zapewne pod wpływem tego powstały na wyspie niedawno dwie inne. [...] Należy galerię odwiedzać. Należy kupować tam obrazy. Helena Rubinstein na pierwszej wizycie kupiła 20 płócien, wśród nich 12 Lebensteinów. Spieszcie się. Wszystko rozkupią ${ }^{23}$.

Dla Lebensteina, w 1959 roku rozpoczął się kilkuletni okres sukcesów artystycznych i finansowych. Malarz „,przylgnął” do Galerie Lacloche, w której wiele sprzedawał, i stał się jednym z najważniejszych malarzy Galerie Lambert. U Romanowiczów Le-

\footnotetext{
${ }^{20}$ Prosząc o uprzejmość dla Adama Schaffa, filozofa marksistowskiego z Warszawy, Jeleński przypominał: „Schaff oddał mi wielką usługę interweniując o Lebensteina — jego udział w wystawie i paszport konsularny”; zob.: J. Giedroyc, K. A. Jeleński, Listy 1950-1987, wybrał, oprac. i wstępem opatrzył W. Karpiński, Warszawa 1995, s. 321.

${ }^{21}$ Z. Romanowiczowa, Jan Lebenstein, s. 163.

22 J. Lebenstein, Polski Paryż. Rozmowa Małgorzaty Smorąg. Ex Libris 1994 nr 44, s. 2-3, przedruk w: Jan Lebenstein. Rozmowy o sztuce własnej, s. 182-186.

${ }^{23}$ K. Wierzyński, Galeria Romanowiczów, Wiadomości 1960 nr 33 (750), s. 4.
} 
benstein miał jednak tylko siedem indywidualnych wystaw. Zauważyć wszelako należy, że były to ekspozycje niezwykle istotne dla jego malarstwa. To właśnie w galerii na wyspie św. Ludwika malarz pokazywał będzie prace będące etapami rozwoju i ewolucji jego twórczości od połowy lat 60 . aż do późnych 70. Sukces finansowy wystaw roku 1959/1960 dał malarzowi pewną niezależność i możliwość wystawiania w najlepszych galeriach europejskich i amerykańskich. Mimo to, jego obrazy, gwasze i rysunki były w stałej ekspozycji i ofercie Galerie Lambert. Miał przywileje:

[...] jak tylko coś miałem gotowego — jakieś grafiki, ilustracje do Orwella na przykład - wspólnie decydowaliśmy, czy warto to pokazać. Galerie Lambert była akurat salą na tego typu wystawy. Małe, kameralne, drobne formy ${ }^{24}$

- wspominał.

Lebenstein brał też udział niemal we wszystkich zbiorowych wystawach organizowanych przez Romanowiczów w Paryżu i na świecie: m.in.: „Ośmiu polskich malarzy” (Avignon 1962), „J. Lebenstein i J. Maeda” (Chicago 1963), „Malarze i rzeźbiarze Galerie Lambert” (Saint-Laurent-du-Pont k/Grenoble 1965), „Lebenstein et les Siens” (Le Théâtre Oblique, Paryż 1974), „15 lat paryskiej Galerii” (Tokio 1974) czy „25 lat Galerie Lambert” (maj-lipiec 1979) ${ }^{25}$. Zawsze nazywany był „malarzem Galerii”.

Nie chciał być emigrantem; podejmując decyzję o pozostaniu we Francji na stałe argumentował: „wolę być na marginesie w Paryżu, niż na marginesie w Warszawie” powie po latach Wiesławie Wierzchowskiej ${ }^{26}$. Związał się z pisarką Olgą Scherer, która mieszkała niedaleko wyspy św. Ludwika i była obecna na wernisażu pierwszej i kolejnych wystaw w Paryżu ${ }^{27}$. (O. Scherer była także autorką jednego z najciekawszych wspomnień o K. A. Jeleńskim ${ }^{28}$.)

Współpraca J. Lebensteina z Romanowiczami nie ograniczała się wyłącznie do działalności galerii. W końcu lat 60. malarz zaprojektował okładkę do wydawanej przez Libellę Romanowicza książki Aleksandra Wata Ciemne świecidło. Brał też udział w promocji książek, których wydawcą była Księgarnia Libella. Wydaje się jednak, że była to przyjacielska przysługa. Przyjaźn z Romanowiczami skwitował wspomnieniem po zamknięciu Galerie Lambert w 1993 roku:

Zasługa Romanowicza polegała nie tylko na robieniu wystaw, ale na pomocy w szerokim tego słowa znaczeniu, ci malarze mieli w nim oparcie, nie tylko w sensie finansowym. To było po prostu przyjazne przyjęcie, otwarty dom, wyciągnięta dłoń, człowiek nie zawsze jest zorientowany w układach paryskich, w zwyczajach, w tym co jest przyjęte. Romanowicz był takim życzliwym człowiekiem, który objaśniał, radził. $Z$ tego często wychodziły zresztą przyjaźnie. [...] To było jedyne takie polskie miejsce w Paryżu ${ }^{29}$.

\footnotetext{
${ }^{24}$ J. Lebenstein, Polski Paryż, s. 183.

${ }^{25}$ A. Olszewska, M. A. Supruniuk, Wystawy w Galerie Lambert (lata 1959-1988), [w:] Libella. Galerie Lambert, s. 110-135.

${ }^{26}$ J. Lebenstein, Malowanie jest jak pisanie dzienników, s. 49. Podobnie w: J. Lebenstein, Artysta o sobie, [w:] Jan Lebenstein. Rozmowy o sztuce własnej, s. 155.

${ }^{27}$ M. A. Supruniuk, Studium bestii, s. 206-208.

${ }^{28}$ O. Scherer, Wspomnienie [o KAJ], oprac. M. Zaborowski, Obecność (Wrocław) 1988 nr 21, s. 42-44.

${ }^{29}$ J. Lebenstein, Polski Paryż, s. 183.
} 


\section{LISTY}

\section{List Konstantego A. Jeleńskiego do Kazimierza Romanowicza [Paryż, 28 kwiet- nia 1959]}

Paris, 28 Avril, 1959.Monsieur C. Romanowicz Galerie Lambert

14 Rue St. Louis-en-1'Ile

PARIS IV $^{\circ}$

Cher Ami,

Je vous envoie une copie de la lettre que j'expédie à Maeda ${ }^{2}$.

Je joins également deux projets de lettres à deux peintres polonais que nous aimerions exposer dans le cadre des accords Galerie Lambert - Congrès pour la Liberté de la Culture ${ }^{3}$. Il est donc bien entendu que l'exposition Lebensztejn et l'exposition Murawska ${ }^{4}$ seront comptes parmi les cinq expositions que nous avons payées d'avance. Il est aussi bien entendu que les frais d'invitations et de publicité de ces expositions seront à notre charge.

Je crois qu'il faut expédier ces deux lettres dès maintenant, car vous connaissez la bureaucratie polonaise: il faudra un certain temps avant que ces deux peintres obtiennent la permission d'expédier leurs tableaux, leurs visas, etc.

Je vous prie de bien vouloir envoyer une copie de la lettre à Mme Murawska, à notre ami J[ózef] Czapski ${ }^{5}$. Il est évident que je soumets ces lettres à votre accord, si leur formulation ne vous convenait pas, je vous prie de me téléphoner.

Je crois que nous avons fait une erreur en envoyant si tôt les invitations pour l'exposition de Dominik ${ }^{6}$. Pour les expositions suivantes, il faudra expédier les invitations une semaine seulement avant le jour du vernissage.

A bientôt j'espère, cordialement,

[Odręcznie:] Dłoń ściskam

[Odręcznie:] Jeleński

$\mathrm{K}$ [onstanty]A[leksander] Jeleński.

$\underline{\text { P.J. }}$

[Na marginesie odręcznie po polsku:] P.S. Myślę że lepiej jest pisać w imieniu Galerie Lambert po francusku. Oczywiście na papierze listowym galerii.

\section{[Maszynopis]}

${ }^{1}$ [Drogi Przyjacielu, Przesyłam Panu kopię listu, który wysłałem do Maedy. Załączam również dwa projekty listów do dwóch polskich malarzy, których chcielibyśmy wystawić w ramach umowy Galeria Lambert - Kongres Wolności Kultury. Jest zatem oczywiste, że wystawa Lebensztejna i wystawa Murawskiej będą wliczone w rachunki pięciu wystaw, które opłaciliśmy z góry. Zrozumiałe jest też, że poniesiemy koszt zaproszeń i reklamy tych wystaw. Myślę, że powinniśmy wysłać te listy już teraz, sam Pan wie jak działa polska biurokracja: to zajmie trochę czasu, zanim ci dwaj malarze uzyskają pozwolenie wysyłania swoich obrazów, wizy, itp. Proszę Pana o przesłanie kopii listu do Pani Murawskiej naszemu przyjacielowi J. Czapskiemu. Oczy- 
wiście przedkładam te listy do Pana akceptacji, jeśli ich formuła Panu nie odpowiada, proszę do mnie zadzwonić. Myślę, że popełniliśmy błąd wysyłając zaproszenia na wystawę Dominika zbyt wcześnie. Przy następnych wystawach, należy wysłać zaproszenia zaledwie na tydzień przed dniem otwarcia. Do zobaczenia wkrótce, mam nadzieję; thum. M. B.]

${ }^{2}$ Josaku Maeda (1926-2007), japoński artysta malarz; w 1957 roku laureat pierwszej nagrody przyznawanej na Międzynarodowej Wystawie Młodych Artystów. W następstwie tej nagrody otrzymał stypendium na studia we Francji przyznawane przez Kongres Wolności Kultury. W czerwcu 1959 roku wystawiał swoje prace w Galerie Lambert. Była to druga wystawa zorganizowana w galerii (po wystawie Tadeusza Dominika). W kolejnych latach działalności Galerie Lambert Maeda brał udział w wielu wystawach zbiorowych oraz paryskich Biennale. W 1961 roku miał kolejną wystawę indywidualną.

${ }^{3}$ Kongres Wolności Kultury (fr.: Congrès pour la Liberté de la Culture), powstał w Paryżu w 1950 roku z inicjatywy członków amerykańskiego stowarzyszenia Komitet Obrońców Wolności Kultury, zrzeszającego intelektualistów - propagatorów antykomunizmu. Zadaniem Kongresu było organizowanie konferencji, sympozjów oraz stwarzanie możliwości wypowiadania się w finansowanych przezeń pismach dla zachodnich intelektualistów. Głównym celem była obrona wolności tworzenia i korzystania $\mathrm{z}$ dóbr kultury, obrona wolności intelektualnej przed cenzurą i wszelkim uciskiem władz komunistycznych i totalitarnych.

${ }^{4}$ Ludmiła Murawska (ur. 1934), polska malarka i aktorka, siostrzenica Ludwika Heringa. W latach 1955-1966 współtworzyła z Ludwikiem Heringiem i Mironem Białoszewskim Teatr Osobny; zob.: Murawska. Malarstwo i Teatr Osobny Trzech Osób. W 1959 roku w Galerie Lambert pokazano prace Murawskiej na wystawie pt. „Sept Jeunes Peintres Polonais” obok prac Przemysława Brykalskiego, Tadeusza Dominika, Zbigniewa Grzybowskiego, Andrzeja Kowalskiego, Teresy Rudowicz, oraz Jerzego Zabłockiego; zob.: A. Olszewska, M. A. Supruniuk, Wystawy w Galerie Lambert (lata 1958-1988), s. 107-135.

5 Józef Czapski (1886-1993), polski malarz i pisarz. Od początku powstania, związany z redakcją paryskiej „Kultury”. W 1974 roku prace Czapskiego zostały pokazane w Galerie Lambert wespół z prezentacją książki Murielle Werner-Gagnebin Czapski - la main et l'espace (Lausanne 1974). Oprócz tego kilkakrotnie jego dzieła pokazywane były na wystawach zbiorowych galerii od 1959 roku; zob.: A. Olszewska, M. A. Supruniuk, Wystawy w Galerie Lambert (lata 1958-1988), s. 110-135.

${ }^{6}$ Tadeusz Dominik (1928-2014), polski malarz, grafik i rzeźbiarz. W latach 1958-1959 przebywał w Paryżu na stypendium ufundowanym przez rząd francuski; zob.: Tadeusz Dominik wczoraj i dziś, red. K. Rutkowska, M. Świątecki, Olsztyn 2006. W roku 1959 wystawa jego malarstwa zainaugurowała działalność Galerie Lambert. Kolejną, indywidualną wystawę, miał T. Dominik w 1962 roku. Oprócz tego, w całym okresie działalności galerii, był prezentowany na wystawach grupowych; zob.: A. Olszewska, M. A. Supruniuk, Wystawy w Galerie Lambert (lata 1958-1988), s. 110-135.

\section{List Kazimierza Romanowicza do Jana Lebensteina [Paryż, 29 kwietnia 1959] $^{1}$}

Monsieur Jan LEBENSZEJN

Paris, le 29 Avril 1959

Ul. Krasińskiego 10, m.50

Warszawa ( Pologne)

Monsieur,

Je m'adresse à vous à le suggestion de notre ami Monsieur K[onstanty] A[leksander] JELENSKI, pour vous proposer une exposition de vos toiles dans ma galerie.

Je prends à ma charge tous les frais: invitations, publicité, etc..., en échange d'une ou de deux de vos toiles. 
Les dimensions de la Galerie Lambert sont de 4.50 X $6 \mathrm{~m}$. Il faut donc que vous apportiez dix à quinze tableaux, à déterminer d'après leurs dimensions.

Il est évident que votre présence à Paris serait absolument nécessaire pour le succès de votre exposition. Je vous propose de l'organiser en Octobre 1959, mais je suis prêt à considérer une autre date, ultérieure, si celle-ci ne vous convenait pas.

En attendant une réponse, je vous prie de croire, cher Monsieur, à mes sentiments les meilleurs et dévoués.

C[asimir] ROMANOWICZ

P.S. Je vous envois, sous pli séparé, l'invitation et l'affiche de notre première exposition qui est celle de Tadeusz DOMINIK. Nous comptons organiser, en 1959, des expositions de jeunes peintres d'avant-garde, dont un Japonais, un Allemand, un Yougoslave $^{2}$.

\section{[Maszynopis]}

${ }^{1}$ [Szanowny Panie, Zwracam się do Pana, za sugestią naszego przyjaciela Pana K[onstantego] A[leksandra] Jeleńskiego, by zaoferować Panu wystawę Pana płócien w mojej galerii. Biorę na siebie wszystkie koszty: zaproszenia, reklamy, itp. ... w zamian za jeden lub dwa Pana obrazy. Wymiary Galerii Lambert są następujące: $4.5 \times 6 \mathrm{~m}$. Trzeba zatem by przywiózł Pan od dziesięciu do piętnastu obrazów, w zależności od ich wymiarów. Jest oczywiste, że Pana obecność w Paryżu będzie absolutnie konieczna by Pańska wystawa odniosła sukces. Proponuję Panu zorganizować ją w październiku 1959, ale jestem skłonny rozważyć inną, późniejszą datę, jeśli ta Panu nie pasuje. W oczekiwaniu na odpowiedź, proszę przyjąć, Szanowny Panie, moje najlepsze życzenia. / K[azimierz] Romanowicz / P.S. W oddzielnej kopercie przesyłam Panu zaproszenie i plakat naszej pierwszej wystawy, wystawy Tadeusza Dominika. Planujemy zorganizować w 1959 roku wystawy młodych malarzy awangardzistów, w tym jednego Japończyka, Niemca i Jugosłowianina; thum. M. B.]

${ }^{2}$ Mowa o wystawach: Josaku Maedy (Japończyka) z lipca 1959, Miljenko Stančiča (Jugosłowianina) z przełomu listopada i grudnia 1959; zob.: A. Olszewska, M. Supruniuk, Wystawy w Galerie Lambert (lata 1958-1988), s. 110. Wystawa malarza niemieckiego Wernera Solika (Sulika?) nie doszła do skutku; zob.: Archiwum Emigracji, Biblioteka Uniwersytecka w Toruniu (dalej: AE), Archiwum Galerie Lambert, list Konstantego A. Jeleńskiego do Kazimierza Romanowicza z 8 czerwca1959.

\section{List Jana Lebensteina do Kazimierza Romanowicza [Warszawa, 11 maja 1959]}

Warszawa 32

ul. Krasińskiego 10 m. 150

Szanowny Panie!

Otrzymałem list Pana z propozycją urządzenia wystawy w Galerie Lambert.

Bardzo dziękuję za tę propozycję, przyjąłem ją z żywą radością.

Także dziękuję Panu za tak korzystne dla mnie warunki ekspozycji, oraz umożliwienie mi wyjazdu do Paryża, co szczególnie mnie cieszy.

Uprzednio otrzymałem list z zapytaniem w tej samej sprawie od naszego przyjaciela p. Jeleńskiego. 
Odpowiadając wysunąłem sugestię, aby wystawę zrobić dopiero w listopadzie.

Podałem kilka powodów, abyście zdecydowali, ja z chęcią przyjmuję Pana propozycję wystawy w październiku, ale gdyby moje sugestie nie za bardzo komplikowały plan pracy galerii, oraz wydały się Wam nie bez racji prosiłbym o termin listopadowy.

Ponieważ z listów wynika, że liczycie październikowy termin, 15 płócien będę w stanie wysłać na początku września, termin ten będzie przeze mnie dotrzymany.

Wysłanie tych prac na koszt własny jest dość drogie i skomplikowane. Dlatego zwróciłem się do prof. Z. Kępińskiego dyr. Muzeum Nar[odowego] w Poznaniu, który obiecał mi ułatwić przesyłkę. Mam nadzieję że nie będzie z tym szczególnych trudności.

Rozmawiałem z nim wczoraj w tej sprawie, stąd też moje opóźnienie odpowiedzi ale musiałem kilka dni czekać na jego przewidziany przyjazd. Bardzo przepraszam za opóźnienie odpowiedzi.

Chciałbym jeszcze zapytać czy te wiązanie nie skomplikuje stosunków (spraw) Pana.

W najbliższych dniach będę wiedział bardziej szczegółowe dane dotyczące przesyłania prac, o czym niezwłocznie napiszę.

Bardzo cieszę się, że ekspozycja będzie w Pana galerii, galerii z którą współpracują Panowie J. Czapski i K. A. Jeleński.

Łączę wyrazy szacunku

Jan Lebensztejn

PS. Proszę b[ardzo] serdecznie pozdrowić Pana J. Czapskiego i Kota [Konstantego A. Jeleńskiego].

Lebensztejn.

[Rękopis]

\section{List Kazimierza Romanowicza do Jana Lebensteina [Paryż, 25 maja 1959]}

Paryż, dnia 25.V.59

Mr. Jan Lebenstejn

Ul. Krasińskiego 10 m. 150

Warszawa 32

Pologne.

Szanowny Panie,

Ogromnie ucieszyłem się Pana listem z dnia 11 b.m. i naturalnie rezerwujemy [dla] Pana galerię na miesiąc LISTOPAD b.r.

Odnośnie wysyłki płócien to wyjaśniam. Wydaje mi się, że najkorzystniej dla Pana byłoby aby płótna przywiózł Pan sam. Uniknęlibyśmy wówczas wszelkich komplikacji celnych tym bardziej, że jeżeli Pan coś na tym terenie sprzeda — a co daj Boże — to musielibyśmy płacić cło za brakujące obrazy przy wyjeździe Pana. Natomiast jak je Pan sam przywiezie - to wówczas wszystkie te komplikacje odpadają. Naturalnie tak 
ta sprawa wygląda z tej strony. Nie znając ani możliwości przywiezienia płócien przez Pana czy też przysłanie tychże małymi partiami przez przyjeżdżających podaję te informacje naturalnie jako teoretyczne - bo może się okazać, że nie może Pan je dostarczyć inaczej jak tylko wysyłając koleją pod naszym adresem. W takim wypadku należy naturalnie podać cenę jak najniższą. (5.000-10.000 frs.) W każdym razie wdzięczny będę za wiadomości odnośnie decyzji Pana co do tych spraw.

Wystawa Dominika, która dobiega końca była ogromnym sukcesem tego młodego malarza. Setki ludzi którzy przyszli na wernisaż, krytyki w prasie polskiej i francuskiej są dowodem, że to dobry malarz. Jestem przekonany, że wystawa Pańska uda się i że będziemy obydwaj z niej zadowoleni.

Łączę wyrazy szacunku i najlepsze słowa ode mnie i Kota.

[Kopia maszynopisu]

5. List Konstantego A. Jeleńskiego do Kazimierza Romanowicza [Paryż, 26 maja 1959! ${ }^{1}$

Paris, 26 Mai, 1959.

Monsieur C[asimir] ROMANOWICZ

Galerie Lambert

14, rue St.-Louis-en-l'Ile

PARIS IV

Cher Ami,

Je vous envoie un projet de lettre à expédier à l'Association des Artistes Polonais. C'est vous qui avez l'adresse exacte, ayant déjà correspondu avec eux.

Si vous connaissez le nom du Directeur ou du Président ${ }^{2}$, il voudrait évidement mieux adresser cette lettre à lui personnellement. Je vous propose d'envoyer des copies de cette lettre à DOMINK, LEBENSZTEJN et MURAWSKA, en mentionnant les copies sur la lettre même, comme je l'ai fait dans mon projet. Auriez-vous aussi la gentillesse d'en envoyer une copie à Czapski et à moi-même, sans en mentionner les copies.

Cordialement,

K[onstanty]A[leksander] Jelenski.

P. J . un projet de lettre.

[Maszynopis]

${ }^{1}$ [Drogi przyjacielu, / Przesyłam Panu projekt pisma do Związku Polskich Artystów Plastyków. To Pan posiada ich dokładny adres, ponieważ już z nimi korespondował. Jeśli zna Pan nazwisko dyrektora lub prezesa, to oczywiście byłoby lepiej zaadresować ten list bezpośrednio do niego. Proponuję wysłać kopie tego listu do Dominika, Lebensztejna i Murawskiej, wskazując 
je w liście, tak jak to zrobiłem w moim projekcie. Czy byłby Pan też na tyle uprzejmy, aby wysłać kopię do Czapskiego i mnie, już bez wspominania o tym; tłum. M.B.]

${ }^{2}$ Listy od Związku Polskich Artystów Plastyków podpisane są przez Stefana Gierowskiego, Sekretarza Zarządu Głównego; zob.: AE, Archiwum Galerie Lambert, listy ZPAP do Kazimierza Romanowicza z 5 czerwca, 6 i 15 lipca 1959.

\section{Projekt listu Kazimierza Romanowicza do Związku Plastyków Polskich [Paryż,

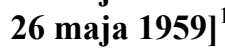

Projet de lettre

Association des Artistes Polonais

Messieurs,

Je pense que vous êtes au courant de la Biennale de Paris, manifestation internationale de jeunes artistes, qui sera organisée par la Ville de Paris, en Octobre 1959. La Pologne a d'ailleurs déjà donné adhésion à cette manifestation.

Monsieur Raymond Coginat ${ }^{2}$, Commissaire de la Biennale, s'est adressé aux galeries parisiennes, en leur demandant de s'associer à la Biennale par le thème de leur expositions tenues au même moment.

Notre Galerie voudrait organiser, dans ce but, une petite exposition collective de jeunes peintres polonais. Nous aimerions exposer sept jeunes peintres ( âgés en principe de 20 à 35 ans ), représentés par deux toiles chacun. Comme nous avons déjà exposés les toiles de Tadeusz DOMINIK que nous continuerons de représenter à Paris, et que nous avons sur notre agenda des expositions de Jan LEBENSZTEJN ( novembre 1959 ) et de Ludmila MURAWSKA ( Décembre 1959 ) nous voudrions évidement inclure ces trois peintres dans ce groupe.

Nous vous proposons de choisir les autres quatre peintres ${ }^{3}$. Les frais des invitations, publicité, etc... sont à la charge de la Galerie Lambert, qui se réserve $33 \%$ $\mathrm{du}$ prix des tableaux, en cas de vente. Si cette proposition vous convient, nous voudrions, par contre, que les frais de transport Varsovie - Paris, et retour, soient couverts par vous, et que vous vous chargiez de rassembler tous les tableaux (à exception de ceux de DOMINIK que nous avons déjà).

Il s'agirait donc pour vous de centraliser douze tableaux (deux de LEBENSZTEJN, deux de MURAWSKA, et deux pour chacun des quatre peintres que vous choisirez), et de nous les expédier à temps. J'espère recevoir sous peu votre réponse de principe, car nous devons prendre une décision définitive à ce sujet, dans un très proche avenir.

Dans l'espoir d'établir avec votre organisation une collaboration fructueuse, je vous prie de croire, Messieurs, à mes sentiments les meilleurs et dévoués.

C[asimir] Romanowicz.

c.c.: Ludmila MURAWSKA,

Tadeusz DOMINIK.

Jan LEBENSZTEJN.

[Maszynopis] 


\begin{abstract}
${ }^{1}$ [Projekt pisma. Związek Polskich Artystów Plastyków / Szanowni Państwo, Sądzę, że jesteście Państwo na bieżąco w kwestii paryskiego Biennale, międzynarodowego wydarzenia dla młodych artystów, które będzie organizowane przez miasto Paryż, w październiku 1959 roku. Polska zgłosiła już uczestnictwo w tym wydarzenia. Pan Raymond Coginat, organizator Biennale, zwrócił się do paryskich galerii, prosząc by przyłączyły się do Biennale poprzez tematykę wystaw przez nie organizowanych w tym samym czasie. Nasza Galeria chciałaby zorganizować w tym celu, małą, zbiorową wystawę młodych, polskich malarzy. Chcielibyśmy przedstawić siedmiu młodych artystów (w wieku od 20 do 35 lat), prezentując po dwa obrazy każdego z nich. Podobnie jak wystawialiśmy obrazy Tadeusza Dominika, które nadal będziemy prezentować w Paryżu, mamy w naszym kalendarzu wystawy Jana Lebensztejna (listopad 1959) i Ludmiły Murawskiej (grudzień 1959), pragniemy włączyć tych trzech malarzy do tej grupy. Proponujemy Państwu wybranie pozostałych czterech malarzy. Koszt zaproszeń, reklamy, itp. ... pozostają po stronie Galerie Lambert, która zastrzega sobie 33 procent ceny obrazu, w przypadku sprzedaży. Jeśli ta propozycja Państwu odpowiada, chcielibyśmy zatem by pokryli Państwo koszty transportu obrazów z Warszawy do Paryża i z powrotem (z wyjątkiem obrazów DOMINIKA, które są już w naszym posiadaniu). Chodziłoby zatem o zebranie przez Państwa dwunastu obrazów (dwa Lebensztajna, dwa Murawskiej oraz po dwa od każdego z czterech wybranych przez Państwa malarzy) i wysłania ich do nas na czas. Mam nadzieję, że wkrótce otrzymam od Państwa odpowiedź, ponieważ musimy podjąć ostateczną decyzję w tej kwestii w bardzo bliskiej przyszłości. W nadziei na nawiązanie z Państwa pomocą owocnej współpracy, przekazuję Państwu moje najlepsze życzenia. / K[azimierz] Romanowicz / do wiadomości: Ludmiły Murawskiej, Tadeusza Dominika, Jana Lebensztejna; tłum. M.B.]

${ }^{2}$ Raymond Coginat (1896-1977), francuski krytyk sztuki, w latach 1957-1977 był redaktorem artystycznej rubryki w paryskiej gazecie „Le Figaro”. W 1959 r. zorganizował paryskie Biennale Młodych Artystów. Był dyrektorem artystycznym Galerie des Beaux-Arts przy rue Faubourg Saint-Honoré w czasie Międzynarodowej Wystawy Surrealizmu.

${ }^{3}$ Mowa o wystawie „Sept Jeunes Peintres Polonais: Przemysław Brykalski, Tadeusz Dominik, Zbigniew Grzybowski, Andrzej Kowalski, Ludmiła Murawska, Teresa Rudowicz, Jerzy Zabłocki”, z października 1959; zob.: A. Olszewska, M. A. Supruniuk, Wystawy w Galerie Lambert (lata 1958-1988), s. 110.
\end{abstract}

\title{
7. List Kazimierza Romanowicza do Jana Lebensteina [Paryż, 27 maja 1959]
}

Paryż, dnia 27.V[19]59

\section{Mr. Jan LEBENSZTEJN}

Ul. Krasińskiego 10 m. 150.

Warszawa 32.

Pologne.

Szanowny Panie,

W załączeniu przesyłam odpis listu jaki w dniu dzisiejszym wysłaliśmy do „Związku Polskich Artystów Plastyków" w Warszawie. Naturalnie projekt naszej wystawy w październiku w ramach „Biennale de Paris” nie ma nic wspólnego z Pańską wystawą indywidualną proponowaną na listopad b.r.

Łączę wyrazy szczerego szacunku i najlepsze słowa.

[Kopia maszynopisu] 


\title{
8. List Konstantego A. Jeleńskiego do Kazimierza Romanowicza [Paryż, 8 czerwca 1959] ${ }^{1}$
}

Paris, 8 Juin, 1959.

\author{
Monsieur C[asimir] ROMANOWICZ \\ Galerie Lambert \\ 14, rue St.-Louis-en-l'Ile \\ PARIS IV
}

Cher Ami,

Voici une copie de l'article que j'ai écrit sur l'exposition de Maeda, et qui paraîtra probablement dans le numéro de Juillet de « Preuves $»^{2}$.

Je vous envoie également une copie de la lettre que je viens d'écrire à Czapski. J'espère que vous allez vous entendre avec lui au sujet de notre, accrohage d'été ${ }^{3}$.

J'ai vu hier le jeune peintre allemand dont je vous avais parlé ${ }^{4}$. Il me semble avoir fait beaucoup de progrès, et je crois que son exposition pourrait apporter à la Galerie Lambert un public nouveau et intéressant. Il est malheureusement impossible que nous fassions son exposition dans le cadre de nos accords. Le peintre allemand est toutefois disposé à couvrir les frais d'invitations, affiches et publicité (je lui ai dit qu'il s'agissait d'une somme environ 100.000 Fr.). Je crois que vous pourriez certainement compter sur une quantité appréciable de ventes. Il s'agit maintenant de déterminer la date de cette exposition. Je vous propose qu'on la fasse en Octobre, si notre plan de jeunes peintres polonais échoue ; sinon, il faudrait la faire en Décembre, après l'exposition Lebensztejn, pour ne pas faire des expositions polonais les unes après les autres. Tout ceci, naturellement, si vous êtes d'accord.

Je vous serais reconnaissant de m'en aviser par lettre. S'il s'agit de l'accrochage d'été, je crois que vous pourriez demander à Marek Rudnicki de vous prêter quelques dessins ${ }^{5}$. Son adresse est: 100, rue Amelot, Paris, $11^{\circ}$ Tél. ROQ. 07-51. Marek Rudnicki pourrait aussi peut-être vous improviser sur-le-champ une unique affiche (à exposer sur la porte de la Galerie) avec les noms des peintres compris dans cet accrochage.

En vous souhaitant du succès pour l'exposition Maeda, je vous envoie, cher Ami, l'assurance de mes amitiés sincères.

[Odręcznie:] Dłoń ściskam

$\mathrm{K}$ [onstanty]A[leksander] Jelenski.

P.J.: 1 copie de l'article.

1 copie de la lettre à J[ózef] Czapski.

\footnotetext{
[Maszynopis]

${ }^{1}$ [Drogi Przyjacielu, Oto kopia artykułu, który napisałem o wystawie Maedy, ukaże się on prawdopodobnie w lipcowym numerze „Preuves”. Przesyłam Panu również kopię listu, który właśnie napisałem do Czapskiego. Mam nadzieję, że dogada się Pan z nim w sprawie naszego letniego accrochage. Wczoraj widziałem się z młodym niemieckim malarzem, o którym Panu mówiłem. Wydaje mi się, że poczynił znaczne postępy, i wierzę, że jego wystawa może przysporzyć Galerie Lambert nowej, interesującej publiczności. Niestety niemożliwe jest zorganizowanie jego wystawy tak, jak to uzgadnialiśmy. Jednak ten niemiecki malarz jest gotów pokryć koszty zaproszeń, plakatów i reklam (powiedziałem mu, że to suma około 100.000 fr). Sądzę, że
} 
z pewnością może Pan liczyć na dużą sprzedaż. Obecnie należy ustalić datę tej wystawy. Proponuję zrobić ją w październiku, jeśli nasz plan co do młodych polskich malarzy nie zawiedzie; jeśli stanie się inaczej, należałoby ją zorganizować w grudniu, po wystawie Lebensztejna, aby nie urządzać wystaw polskich artystów jedna po drugiej. Wszystko to, oczywiście, jeśli się Pan zgadza. Byłbym wdzięczny gdyby odpowiedział mi Pan listownie. Jeśli chodzi o letni accrochage, sądzę, że może Pan poprosić Marka Rudnickiego aby Panu pożyczył kilka rysunków. Jego adres to: 100, rue Amelot, Paryż, $11^{\circ}$ tel.: ROQ. 07-51. Marek Rudnicki na poczekaniu może stworzyć dla Pana unikalny plakat (do powieszenia na drzwiach Galerii) z nazwiskami artystów biorących udział w accrochage. Życząc sukcesów na wystawie Maedy, przesyłam Panu, Drogi Przyjacielu, wyrazy mojej szczerej przyjaźni; tłum. M.B.]

2 „Preuves”, francuskie czasopismo antykomunistyczne, które wydawane było w latach 50 . i 60. w Paryżu pod redakcją François Bondy. Poruszało tematykę kulturalno-polityczną. Magazyn finansowany był przez Kongres Wolności Kultury; zob.: François Bondy i pismo „Preuves”, http://www.gombrowicz.net/Francois-Bondy-i-pismo-Preuves.html [dostęp: 23.03.2015].

3 accrochage d'été (fr.) - sezonowa wystawa grupowa (w tym przypadku letnia). Wystawy te regularnie organizowane były w Galerie Lambert; wystawiano na nich zaprzyjaźnionych z galerią artystów. W powyższym liście mowa o accrochage z lipca 1959 roku, na którym zaprezentowano prace: Leonor Fini, Józefa Czapskiego, Stanislao Lepri, Nikifora, Josaku Maedy, Edwarda Matuszczaka, Tadeusza Dominika, Mieczysława Tadeusza Janikowskiego, J. Verneta, Floristelli Stephani, Colombotto-Rosso; zob.: A. Olszewska, M. A. Supruniuk, Wystawy w Galerie, s. 110.

${ }^{4}$ Zob. list 2 przyp. 2.

${ }^{5}$ Marek Rudnicki, (1927-2004), polski artysta grafik, portrecista Akademii Francuskiej, ilustrator książek; zob.: M. Wittbrot, Braterstwo. Z Markiem Rudnickim rozmawia Marek Wittbrot, Recogito $2005 \mathrm{nr}$ 36, http://www.recogito.pologne.net/recogito_36/znakil.htm [dostęp: 23.03.2015]. W Galerie Lambert Rudnicki miał swoją indywidualną wystawę w 1965 roku. Jego prace pokazywano też na kilku wystawach zbiorowych; zob.: A. Olszewska, M. A. Supruniuk, Wystawy w Galerie Lambert (lata 1958-1988), s. 118, 126.

\section{List Jana Lebensteina do Kazimierza Romanowicza [Warszawa, 8 lipca 1959]}

8.7.59, Warszawa

\section{Szanowny Panie}

bardzo dziękuję za zaproszenie na wystawę w Pana Galerii w ramach Biennale de Paris.

Oczywiście wezmę w tym udział.

Także dziękuję za przesunięcie wystawy mojej na listopad b.r.

Odnośnie wysyłki płócien — w pełni rozumiem Pana propozycję i jeżeli będzie to tylko możliwe przywiozę płótna sam, z tym że nie bardzo wydaje mi się to możliwe. Obecnie wyjeżdżając do Francji dostaje się bilet lotniczy, tylko w bardzo wyjątkowych okolicznościach można otrzymać przejazd koleją.

Podróż samolotem skazuje na bardzo ograniczony bagaż, płótna są dość grubo malowane, zdjęcie z blejtramów równa się zniszczeniu. I ręczę, że oprawa na miejscu też byłaby kosztowna.

Aby przesłać przez znajomych to trzeba mieć entuzjastów.

Postaram się aby wysyłka odbyła się bez...., ceny przez Pana podane, nadawca nieprowokujący.

Gdyby udało się coś w Paryżu sprzedać, cło pokryłbym z sumy przypadającej dla mnie.

Cieszę się że wystawy urządzane w Galerie Lambert mają tak duże powodzenie. 
Dziękuję za zaproszenie na wystawę Maeda. Malarz ten wydaje mi się b[ardzo] interesujący. Ciekaw jestem jak została przyjęta jego wystawa?

Zwracam się do Pana z prośbą, czy mógłby mi Pan przesłać pisemną deklarację stwierdzającą (zobowiązującą się), że galeria opłaci mój pobyt we Francji?

Jest to niezbędnie potrzebne do uzyskania paszportu. Forma deklaracji albo gwarancja zakupu, albo zaproszenie.

Suma zadeklarowana 120-150 dol. tyle ile wynosi miesięczne stypendium krajowe.

Gdyby to było możliwe bardzo bym prosił o wysłanie takiego pisma.

Pobyt mój w Paryżu właściwie jest już zabezpieczony, ponieważ mam wyżej wymienioną kwotę odebrać w Paryżu, za obraz który kupił u mnie o. Joseph Alsop ${ }^{1}$.

Na Biennale de Paris będę miał 2-3 płótna w ramach ekspozycji krajowej.

Może na wiosnę 1960 roku będę miał wystawę indywidualną, nie wiem jeszcze w jakiej galerii. Załatwia mi to Lady Norton znajoma p. Czapskiego.

Jeszcze w sprawie zaproszenia. Co ja mam przygotować?

Łączę wyrazy szacunku oraz najlepsze słowa dla Pana i dla Kota.

Lebensztejn

\section{[Rękopis]}

${ }^{1}$ Joseph Alsop, właśc. Joseph Wright Alsop V (1910-1989), amerykański dziennikarz, publicysta, współpracownik i korespondent „New York Herald Tribune”. Posiadanie prac Lebensteina przez J. Alsopa potwierdza Jan K. Kapera, Od Guggenheim Museum do Currier Gallery. Jan Lebenstein - kronika amerykańska (1959-1998), Archiwum Emigracji. Studia - Szkice Dokumenty 1999 z. 2, s. 61. J. Alsop w czerwcu 1959 roku był w Warszawie i tam zapoznał się z nową sztuką polską. Napisał na ten temat kilka artykułów do „New York Herald Tribune”, m.in.: J. Alsop, Polish artists have sense of historic missions, przedr. w: The Victoria Advocate (Victoria, Texas), 9.06.1959, s. 4, http://news.google.com/newspapers?nid=861\&dat $=19590609$ \&id=JlBTAAAAIBAJ\&sjid=94cDAAAAIBAJ\&pg=5193,892808 [dostęp, 17.02.2015]; tenże, Polish artists reject official realism of Stalinist times, przedr. w: Toledo Blade, 3.06.1959, s. 28 http://news.google.com/newspapers?nid=1350\&dat=19590603\&id=mL1OAAAAIBAJ\&sjid=9A AEAAAAIBAJ\&pg=7595,4987992 [dostęp, 17.02.2015]; tenże, Poland's painters enjoy their „Day's lovely light”, przedr. w: Eugene Register Guard, 4.06.1959, http://news.google.com/ newspapers?nid $=1310 \&$ dat $=19590604 \& \mathrm{id}=$ GM8TAAAAIBAJ $\&$ sjid $=7$ uIDAAAAIBAJ\&pg $=344$ 1,591783 [dostęp, 17.02.2015].

\section{List Kazimierza Romanowicza do Jana Lebensteina [Paryż, 17 lipca 1959] ${ }^{1}$}

Paris, le 17.VII.59

Monsieur Jan LEBENSZTEJN

Ul. Krasińskiego 10 m. 150.

Warszawa 32.

Pologne.

Cher Monsieur,

Je vous écris pour vous confirmer définitivement la proposition que je vous ai faite récemment d'exposer vos tableaux dans ma galerie, du 10 Novembre, au 1 Décembre 1959. 
Il est entendu que la Galerie vous achètera un ou deux tableaux pour la somme de soixante-quinze mille frs., afin de vous permettre de couvrir vos frais de séjour à Paris, étant donné que votre présence, pendant l'exposition, nous parait essentiel.

J'espère que vous allez, dès maintenant, vous occuper de l'expédition des tableaux que nous voudrions recevoir pas plus tard que le 1 Novembre prochain.

Il est naturellement entendue qu'en cas de vente de toiles, la Galerie Lambert conserve $33 \%$ de leur prix.

En espérant avoir bientôt de vos nouvelles, je vous prie de croire, cher Monsieur, à mes sentiments les meilleure et dévoués.

C[asimir] Romanowicz.

[Kopia maszynopisu]

${ }^{1}$ [Szanowny Panie, Piszę, aby ostatecznie potwierdzić propozycję, jaką Panu złożyłem w sprawie wystawy Pana obrazów w mojej galerii od 10 listopada do 1 grudnia 1959. Przyjęliśmy, że Galeria zakupi od Pana jeden lub dwa obrazy za kwotę siedemdziesięciu pięciu tysięcy franków, co umożliwi pokrycie kosztów Pana pobytu w Paryżu ponieważ Pana obecność, podczas wystawy, wydaje się nam niezbędna. Mam nadzieję, że od teraz zajmie się Pan wysyłką obrazów, które chcielibyśmy otrzymać nie później niż 1 listopada. Jest to oczywiście zrozumiałe, że w przypadku sprzedaży obrazów, Galeria Lambert zachowuje 33\% ich ceny. Mając nadzieję wkrótce otrzymać od Pana wiadomość, przekazuję Panu najlepsze życzenia; tłum. M.B.]

\section{List Kazimierza Romanowicza do Jana Lebensteina [Paryż, 19 września 1959]}

Paryż, dnia 19.IX.59

Monsieur Jan LEBENSZTEJN

Ul. Krasińskiego 10 m. 150

Warszawa 32

Pologne.

Szanowny i Drogi Panie,

Jeszcze jeden list aby przypomnieć Panu o Jego wystawie a co najważniejsze aby na zasadzie zdobytego doświadczenia powiedzieć Panu, że już teraz i to „całą parą” musi Pan zacząć starania wyjazdowe tak dla Pana jak i dla Jego obrazów.

Obrazy na które czekam na wystawę „SEPT JEUNES PEINTRES POLONAIS” dotychczas do mnie nie dotarły, jakkolwiek miałem zapewnienie ze Związku Plastyków, że zostały wysłane w sierpniu. (!). Mam nadzieję, że przyjdą jeszcze na czas ale w związku z powyższym to dobra przestroga dla Pana jak to wszystko długo idzie. Gdyby Pan wysyłał obrazy koleją - to MUSI Pan je wysłać jako przesyłkę „EXPRESS” — inaczej bowiem może iść całymi tygodniami.

$\mathrm{Na}$ zakończenie wreszcie moja prośba osobista. Gdyby Pan natrafił przypadkowo na jakiegoś dobrego Nikifora - ogromnie proszę o zakupienie go dla mnie — zwrócę należność Panu na miejscu i we frankach ${ }^{1}$. Serdecznie z góry dziękuję.

Oczekując na słowo wiadomości, łączę wyrazy szczerego szacunku i najlepsze słowa.

C[asimir] Romanowicz 
[Kopia maszynopisu]

${ }^{1}$ Nikifor miał w 1959 roku indywidualną wystawę w Paryżu, w galerii Diana Vierny. Wystawa wzbudziła duże zainteresowanie krytyki francuskiej, czego przykładem był tekst Jean’a Grenier'a, opublikowany w paryskiej „Kulturze”; zob.: J. Grenier, Nikifor, Kultura $1959 \mathrm{nr} 6$ (140), s. 141-142. Józef Czapski zauważył: „Już o wystawie Nikifora, skromnej i zachwycającej, powiedzieć możemy, że była sukcesem. «Express» pisze o niej: «Nikifor dzisiaj w szpitalu maluje dalej, nie troszcząc się o to, że wśród tylu wystaw, jednej świetniejszej niż druga, jego wystawa jest w tej stolicy malarstwa może rewelacją roku»"; zob.: J. Czapski, Galerie Lambert, Kultura $1959 \mathrm{nr} 6(140)$, s. 143.

\section{List Konstantego A. Jeleńskiego do Kazimierza Romanowicza [Paryż, 21 wrze- śnia 1959] ${ }^{1}$}

Paris, 21 Septembre, 1959.

Monsieur C[asimir] Romanowicz

Galerie Lambert

14, Rue St Louis-en-1'Ile

PARIS IV ${ }^{\circ}$

Cher Ami,

Je vous envoie ci-joint trois projets de lettre à expédier aux peintres que nous envisagerons d'exposer prochainement.

Je viens d'avoir une lettre de Lebensztejn qui m'annonce son arrivée à Paris après le 15 Octobre. Je lui ai écrit pour lui dire mon espoir de le voir apporter ses tableaux ; ceci nous donnera naturellement du temps pour organiser son exposition.

Lebensztejn a été à Venise à l'exposition de la peinture polonaise contemporaine ${ }^{2}$. Parmi les vingt peintres qui y représentaient la peinture polonaise, il y avait Domnik et Lebensztejn. J'ai demandé à ce dernier de nous envoyer plusieurs exemplaires du catalogue de cette exposition.

Je passerai vous voir très prochainement pour vous remettre les invitations que j'ai signées.

Bien amicalement,

[Odręcznie:] Dłoń ściskam

$\mathrm{K}$ [onstanty]A[leksander] Jelenski.

P. J .

[Kopia maszynopisu]

${ }^{1}$ [Drogi Przyjacielu, Przesyłam Panu w załączeniu trzy projekty listów do wysłania do malarzy, których mamy zamiar niedługo wystawić. Właśnie dostałem list od Lebensztejna, który zapowiada swój przyjazd do Paryża 15 października. Odpisałem mu, że mam nadzieję, że przywiezie ze sobą swoje obrazy; to dałoby nam czas na przygotowanie jego wystawy. Lebensztejn był w Wenecji na wystawie polskiego współczesnego malarstwa. Wśród dwudziestu artystów, reprezentujących tam malarstwo polskie, był Dominik i Lebensztejn. Poprosiłem tego drugiego 
aby wysłał nam kilka egzemplarzy katalogu tej wystawy. Przybędę do Pana wkrótce by przekazać podpisane przeze mnie zaproszenia; tłum. M.B.]

23 września 1959 roku, w Wenecji otwarta została wystawa polskich artystów. Informacje o tej wystawie są szczątkowe; zob.: Kalendarium, Przegląd Artystyczny 1959 nr 4, s. 52. Następnie wystawa została przeniesiona do Genewy i ponownie otwarta 23 października w Musée d'Art et d'Histoire (Pologne - 50 ans de peinture, [katalog wystawy], Musée d'Art et d'Histoire Geneve, 24 octobre - 29 novembre 1959, [oprac.] R. Stanisławski, Geneve 1959). Oprócz Jana Lebensteina i Tadeusza Dominika na wystawie pokazywano prace m.in. Jana Tarasina, Ariki Madeyskiej, Aleksandra Kobzdeja, Aliny Szapocznikow, Witolda Wojtkiewicza, Władysława Strzemińskiego, Rajmunda Ziemskiego; zob.: H. St., 50 ans de peinture en Pologne, Das Werk 1959 nr 12, s. 229-230.

\section{LITERATURA}

Archiwum Emigracji BU w Toruniu, Archiwum Galerie Lambert;

J. Giedroyc, K. A. Jeleński, Listy 1950-1987, wybrał, oprac. i wstępem opatrzył W. Karpiński, Warszawa 1995;

P. Grémion, Konspiracja wolności. Kongres Wolności Kultury w Paryżu (1950-1975), Warszawa 2004;

J. Lebenstein, Światto i przestrzeń, Jan Lebenstein. Rozmowy o sztuce własnej, o tradycji $i$ współczesności, wybór i oprac. A. Wat, D. Wróblewska, wstępem opatrzył K. Pomian, Warszawa 2004;

Jan Lebenstein i krytyka. Eseje, recenzje, wspomnienia, wybór i oprac. A. Wat, D. Wróblewska, wstępem opatrzyła J. Sosnowska, Warszawa 2004;

Libella Galerie Lambert. Szkice i wspomnienia, red. i oprac. M. A. Supruniuk, Toruń 1998;

L. Murawska-Peju, Posłowie, [w:] L. Hering, Ślady, Warszawa 2011;

Murawska. Malarstwo i Teatr Osobny Trzech Osób (Białoszewski, Hering, Murawska), oprac. M. A. Supruniuk, Toruń 1999;

M. A. Supruniuk, Przyjaciele wolności. Kongres Wolności Kultury i Polacy, Warszawa 2008;

M. A. Supruniuk, Studium bestii. Jan Lebenstein i Galerie Lambert (w 40-lecie pierwszej wystawy), [w:] Jan Lebenstein i krytyka. Eseje, recenzje, wspomnienia, wybór i oprac. A. Wat, D. Wróblewska, wstępem opatrzyła J. Sosnowska, Warszawa 2004.

\section{JAN LEBENSTEIN AND GALERIE LAMBERT IN 1959. THE CIRCUMSTANCES OF THE FIRST EXHIBITION}

In 1959, Jan Lebenstein, a distinguished painter had his first two exhibitions in Paris. The featured correspondence between the painter, Galerie Lambert in Paris, Kazimierz Romanowicz and Konstanty A. Jeleński sheds light on the circumstances of those exhibitions and the problems faced by Polish visual artists during the Cold War.

Keywords: Jan Lebenstein, Konstanty A. Jeleński, Galerie Lambert in Paris, Galerie Lacloche in Paris, Biennale des Jeunes de Paris. 